\title{
TECHNIQUES OF PAIN REDUCTION IN THE NORMAL LABOR PROCESS : SYSTEMATIC REVIEW
}

\author{
Wan Anita \\ STIKes Tengku Maharatu Pekanbaru \\ wan_anita77@yahoo.co.id \\ Submitted :11-08-2017, Reviewed:27-08-2017, Accepted:29-08-2017 \\ DOI: http://doi.org/10.22216/jen.v2i3.2357
}

\begin{abstract}
Pain during labor is a physiological condition commonly experienced by most maternity mothers. Labor pain is a subjective experience caused by uterine muscle ischemia, withdrawal and traction of uterine ligaments, ovarian traction, fallopian tubes and lower uterine distension, pelvic floor muscles and perineum. The pain in labor arises from psychic responses and physical reflexes. The purpose of this Systematic review is to look at effective methods for reducing pain in the labor process so that it can be used as an alternative method of reducing pain in patients who will give birth. This review systematic review of the published artike through google scholar site with 17 journals reviewed. In an effort to reduce labor pain there are various methods that can be used in providing midwifery care in the process of childbirth. Based on this systematic review it can be concluded that many methods of pain reduction that can be used in reducing labor pain are counter pressure and abdominal lifting, hypnobirthing, religious and murottal music, classical music and local music, relaxation, compress, warm ginger drink, acupressur, TENS, account and aromatherapy.
\end{abstract}

Keywords: technique, labor pain

\begin{abstract}
ABSTRAK
Nyeri saat persalinan merupakan kondisi fisiologis yang secara umum dialami oleh hampir semua ibu bersalin. Nyeri persalinan merupakan sebuah pengalaman subjektif disebabkan oleh iskemik otot uteri, penarikan dan traksi ligament uteri, traksi ovarium, tuba fallopii dan distensi bagian bawah uteri, otot dasar panggul dan perineum. Apabila nyeri persalinan tidak diatasi akan menyebabkan terjadinya partus lama. Tujuan Systematic review ini untuk melihat metode yang efektif untuk mengurangi rasa nyeri dalam proses persalinan sehingga dapat dijadikan metode alternative pengurangan rasa nyeri pada pasien yang akan melahirkan. Systematic review ini menelaah dari artike yang dipublikasi melalui situs google scholar dengan 17 jurnal yang direview. Dalam upaya mengurangi rasa nyeri persalinan terdapat berbagai metode yang dapat digunakan dalam memberikan asuhan kebidanan dalam proses persalinan. Berdasarkan systematic review ini dapat disimpulkan bahwa banyak metode pengurangan rasa nyeri yang dapat digunakan dalam mengurangi nyeri proses persalinan adalah metode counter pressure dan abdominal lifting, hypnobirthing, music religi dan murottal, music klasik dan music daerah, relaksasi, kompres, minuman jahe hangat, akupressur, TENS, account dan aromatherapy.
\end{abstract}

Kata Kunci : teknik, nyeri persalinan

\section{PENDAHULUAN}

Nyeri saat persalinan merupakan kondisi fisiologis yang secara umum dialami oleh hampir semua ibu bersalin. Nyeri persalinan merupakan sebuah pengalaman subjektif disebabkan oleh iskemik otot uteri, penarikan dan traksi ligament uteri, traksi ovarium, tuba fallopii dan distensi bagian bawah uteri, otot dasar panggul dan perineum. Nyeri persalinan mulai timbul pada kala I fase laten dan fase aktif, pada fase laten terjadi pembukaan serviks sampai $3 \mathrm{~cm}$ bisa berlangsung selama 8 jam. Nyeri disebabkan oleh kontraksi uterus dan dilatasi serviks. Dengan seiring bertambahanya intensitas dan frekuensi kontraksi uterus nyeri yang dirasakan akan bertambah kuat, puncak 
nyeri terjadi pada fase aktif dimana pembukaan lengkap sampai $10 \mathrm{~cm}$ dan berlangsung sekitar 4,6 jam untuk primipara dan 2,4 jam untuk multipara (Reeder, Martin \& Koniak-Griffin, 2012).

Rasa nyeri pada persalinan muncul akibat respons psikis dan refleks fisik. Nyeri akan berdampak pada peningkatan aktivitas sistem saraf simpatik yang dapat mengakibatkan perubahan tekanan darah, denyut nadi, pernafasaan, dan warna kulit, mual muntah, dan juga keringat berlebihan. Perubahan tingkah laku tertentu akibat nyeri juga sering terlihat seperti peningkatan rasa cemas dengan pemikiran yang menyempit, mengerang, menangis, gerakan tangan dan ketegangan otot yang sangat di seluruh tubuh. Ketegangan emosi akibat rasa cemas dan rasa takut dapat memperberat persepsi ibu terhadap nyeri selama persalinan. Nyeri persalinan akan menimbulkan ketakutan sehingga muncul kecemasan yang berakhir dengan kepanikan (Bobak, 2005). Nyeri persalinan juga dapat menyebabkan timbulnya hiperventilasi sehingga kebutuhan oksigen meningkat, kenaikan tekanan darah, dan berkurangnya motilitas usus serta vesika urinaria. Keadaan ini akan merangsang peningkatan katekolamin yang dapat menyebabkan gangguan pada kekuatan kontraksi uterus sehingga terjadi inersia uteri. Apabila nyeri persalinan tidak diatasi akan menyebabkan terjadinya partus lama (Llewllyn, 2001).

Upaya untuk mengurang kecemasan dalam persalinan tidak hanya dilakukan oleh tenaga kesehatan, tetapi dukungan keluarga sangat berperan dalam mengurangi kecemasan yang dapat berdampak pada persalinan. Penelitian oleh Sari \& Novriani (2017) menggambarkan bahwa $(80 \%)$ mendapatkan dukungan dari keluarga dan $(53,3 \%)$ mengalami kecemasan ringan, (20\%) mengalami panik, (16,7\%) mengalami kecemasan sedang dan $10 \%$ responden mengalami kecemasan berat. Pada analisa bivariat $\mathrm{p}$ value $=0,041$ terdapat hubungan antara dukungan keluarga dengan tingkat kecemasan menjelang persalinan trimester ketiga. Keluarga memberikan dukungan pada ibu menjelang persalinan agar ibu merasa tenang dan mengurangi kecemasan ibu menjelang persalinan.

Penelitian oleh Afritayeni (2017) yang meneliti tentang hubungan umur, paritas dan pendamping persalinan terhadap nyeri persalinan. Hasil penelitian menunjukkan ada hubungan yang signifikan antara usia dengan intensitas nyeri persalinan dengan $\mathrm{P}$ Value $=0.001$, ada hubungan yang signifikan antara paritas dengan intensitas nyeri persalinan dengan $P$ Value $=0.000$ dan ada hubungan yang signifikan antara pendamping persalinan dengan intensitas nyeri persalinan dengan $\mathrm{P}$ Value $=0.023$.

Penelitian oleh Anisyah Dwi Puspita dan Warsiti (2013), menganalisis faktorfaktor yang mempengaruhi nyeri persalinan pada ibu bersalin kala I fase aktif di Puskesmas Mergangsan tahun 2013 terhadap 57 responden yang akan melahirkan menunjukkan sebanyak 57,9 \% responden mengalami nyeri persalinan sedang, faktor yang memiliki hubungan dengan nyeri persalinan yaitu umur ibu $(\mathrm{p}=$ $0,021)$, paritas $(\mathrm{p}=0,000)$, pesepsi $(\mathrm{p}=0,000)$ dan kecemasan $(\mathrm{p}=0,01)$. Penelitian yang dilakukan oleh Afifah, Mulyono, \& Pujiati (2012) untuk melihat perbedaan tingkat nyeri persalinan terhadap 15 ibu primigravidan dan 15 ibu multigravida pada persalinan normal kala I. Hasil penelitian menunjukkan bahwa nyeri persalinan pada ibu primigravida 10 orang $(66,7 \%)$ mengalami nyeri berat, 4 orang 
(26,7\%) mengalami nyeri sedang dan 1 orang $(6,7 \%)$ nyeri sangat berat sedangkan nyeri persalinan pada ibu multigravida terdapat 9 orang $(60 \%)$ mengalami nyeri ringan dan 6 orang (40\%) mengalami nyeri sedang. Terdapat perbedaan tingkat nyeri persalinan kala I pada ibu bersalin normal primigravida dan multigravida $\mathrm{p}$ value $=$ 0,000. Ada perbedaan tingkat nyeri persalinan kala I pada ibu bersalin normal primigravida dan multigravida di RB Nur Hikmah Desa Kuwaron Gubug Kabupaten Grobogan $(\mathrm{p}$ value $=0,000<0,05)$.

Kebutuhan ibu melahirkan untuk mengatasi nyeri selama proses persalinan teridentifikasi enam tema yang saling berhubungan dengan tujuan khusus, yaitu respon fisik, respon psikologi, upaya penangan mandiri, keberhasilan penanganan, upaya petugas dan pelayanan keperawatan professional (Setyowati, 2013). Berbagai metode digunakan untuk menggunakan mengurangi rasa nyeri persalinan baik menggunakan obat-obatan maupun metode komplementer.

Berdasarkan latar belakang diatas, maka perlu dilakukannya tinjauan Systematic review mengenai metode pengurangan rasa nyeri dalam proses persalinan. Systematic review mengidentifikasi berbagai metode pengurangan rasa nyeri dalam proses persalinan. Tujuan Systematic review ini juga untuk melihat metode yang efektif untuk mengurangi rasa nyeri dalam proses persalinan sehingga dapat dijadikan metode alternative pengurangan rasa nyeri pada pasien yang akan melahirkan.

\section{METODE PENELITIAN}

Penelitian ini menggunakan metode systematic review. Sumber data penelitian ini berasal dari literatur yang diperoleh dari hasil penelitian (artikel penelitian) tentang teknik/metode pengurangan rasa nyeri dalam proses persalinan normal yang dipublikasikan di internet.

Pencarian literatur dilakukan secara komputerisasi dengan data base elektronik google scholar. Kata kunci pencarian antara lain persalinan, kontraksi, kebidanan, nyeri persalinan, pengobatan alternatif, komplementer, kedokteran, hypnosis, aromatherapy, sterile water injection, inhaled analgesia, TENS, relaksasi, kompres panas, kompes dingin, epidurals, counter pressure, akupressure metakarpal, deep back massage, endorphin massage, hypnobirthing, hypnotherapy, teknik zilgrei, teknik kneading, musik bali, musik jawa/gamelan, musk instrumental, musik klasik, musik religi, murotal, effluerge, teknik lamaze, minuman jahe hangat, pernafasan lambat, teknik acount.

Setelah artikel tersebut ditemukan melalui pencarian google scholar selanjutnya dievaluasi sesuai kriteria yaitu teknik pengurangan rasa nyeri dalam proses persalinan dan ditelaah untuk di-review sejumlah 17 artikel. Teori lain juga digunakan dalam penelitian ini untuk memperkuat alasan dari literatur yang dikaji. Analisis bivariat untuk melihat pengaruh/perbedaan tekinin/metode yang digunakan dalam mengurangi rasa nyeri dalam proses persalinan.

\section{HASIL DAN PEMBAHASAN}

Strategi pencarian yang telah dilakukan, didapatkan 18 penelitian RCT (eksperimen) dengan teknik / metode dalam pengurangan rasa nyeri dalam persalinan. Penelitian tersebut terdiri dari teknik / metode : counter pressure dan abdominal lifting, hypnobirthing, masase pada punggung (kadar endorphin), Endorphin Massage, Metode Massage Effleurage, Teknik Relaksasi, Metode Zilgrei dan 
endorphin massage, Distraksi musik klasik dengan murotal, Teknik relaksasi lamaze, Teknik relaksasi nafas dalam, Terapi kompres hangat, metode Acount, Musik klasik Mozart dan tradisional gamelan jawa, minum jahe hangat, Pijat punggung, Acupressure metacarpal, Terapi murottal, Terapi music religi, Masase punggung dengan teknik effluerage, Terapi musik klasik dan musik Bali, Akupressur titik pada tangan, TENS, Kompres air hangat, Metode Transcutaneus Electical Nerve Stimulation (TENS), Aromatherapy Jasmine. Semua eksperimen disimpulkan dalam table dan dideskripsikan secara detail. Berdasarkan review terhadap beberapa penelitian tentang teknik / metode dalam pengurangan nyeri dalam persalinan antara lain :

\section{Metode Counter pressure dan abdominal lifting}

Penelitian oleh Angraeni et al. (2013) tentang efektifitas teknik abdominal lifting dan counter pressure dalam mengatasi nyeri persalinan fase aktif kala I di RSUD Tidar Kota Magelang terhadap 48 responden dalam kala I persalinan fase aktif. Kelompok perlakukan adalah diabdominal lifting 24 orang dan kelompok counter pressure 24. Penelitian ini merupakan penelitian kuasi eksperimen dengan two group posttest only design untuk mengetahui efektifitas antara counter pressure dan abdominal lifting dalam menurunkan nyeri fase aktif kala I. Alat pengumpulan data menggunakan McGill Pain Quesioner. Teknik counter pressure dilakukan di daerah lumbal di mana saraf sensorik rahim dan mulut rahim berjalan bersama saraf simpatis rahim memasuki sumsum tulang belakang melalui saraf torakal 10-11-12 sampai lumbal 1. Dengan begitu impuls rasa sakit ini dapat diblok yaitu dengan memberikan rangsangan pada saraf yang berdiameter besar yang menyebabkan gate control akan tertutup dan rangsangan sakit tidak dapat diteruskan ke korteks serebral (Mander, 2003). Teknik counter pressure melakukan pemblokiran impuls nyeri yang akan di transmisikan ke otak lebih cepat dibandingkan dengan cara kerja abdominal lifting. Teknik abdominal lifting dilakukan dengan cara memberikan usapan berlawanan ke arah puncak perut tanpa menekan ke arah. Hal tersebut dapat merangsang serat saraf besar meningkatkan mekanisme aktivitas substansia gelatinosa yang mengakibatkan tertutupnya pintu mekanisme sehingga aktivitas sel $\mathrm{T}$ terhambat dan menyebabkan hantaran rangsangan ikut terhambat dan nyeri tidak akan dihantar ke korteks serebri (Hidayat, 2006). Proses tersebut lebih lambat daripada pemblokiran impuls nyeri ketika dilakukan teknik counter pressure. Hasil penelitian menunjukkan paritas responden diketahui bahwa pada kelompok abdominal lifting jumlah persalinan (paritas) responden didominasi oleh kelompok multipara sebanyak 15 responden $(62,5 \%)$ sama halnya pada kelompok counter pressure yang juga didominasi oleh kelompok multipara dengan responden lebih besar yaitu sebanyak 17 responden (70.8\%). Hasil untuk kelompok abdominal lifting mayoritas responden berada pada skala nyeri antara 40-49 sebanyak 13 responden $(54,2 \%)$, sebanyak 7 responden $(29,2 \%)$ berada pada skala nyeri 50-59 dan sebanyak 4 responden $(16,6 \%)$ berada pada skala nyeri 30-39. Sedangkan pada kelompok counter pressure mayoritas responden berada pada skala nyeri antara 40-49 sebanyak 11 responden $(45,8 \%)$, sebanyak 10 responden $(41,7 \%)$ berada pada skala nyeri 30-39 dan sebanyak 3 responden $(12,5 \%)$ berada pada skala nyeri 50-59. Hasil uji t-test independent 
didapatkan hasil bahwa Sig (2-tailed) menunjukan nilai 0,031 ( $\mathrm{p}$ value $<\alpha 0,05$ ) dan t tabel 2,220 sehingga didapatkan hasil bahwa H0 ditolak dan $\mathrm{Ha}$ diterima. Kesimpulan penelitian ini adalah adanya perbedaan yang signifikan antara teknik abdominal lifting dan counter pressure dalam mengatasi nyeri persalinan fase aktif kala I. Dengan demikian dari kedua teknik tersebut yang lebih efektif mengurangi nyeri adalah teknik counter pressure dengan hasil mean $43<$ mean teknik abdominal lifting sebesar 46.58. Hasil uji regresi linier didapatkan hasil bahwa nilai $\mathrm{p}$ untuk usia adalah 0,287 dan nilai $\mathrm{p}$ untuk paritas sebesar 0,855 artinya bahwa nilai $\mathrm{p}$ dari kedua variabel tersebut $p$ value $>0,05$ yang artinya bahwa tidak ada pengaruh antara usia dan paritas terhadap nyeri persalinan. Pada penelitian ini memberikan hasil bahwa terdapat perbedaan antara kelompok yang diberikan tindakan abdominal lifting dan counter pressure, counter pressure lebih efektif dalam dalam mengatasi nyeri persalinan fase aktif kala I dengan hasil mean 43 lebih kecil mean teknik abdominal lifting sebesar 46.58.Penelitian oleh Azizah, Widyawati, \& Anggraini (2011) tentang pengaruh endorphin massage terhadap intensitas nyeri kala i persalinan normal ibu primipara di BPS $\mathrm{S}$ dan B demak tahun 2011. Desain penelitian adalah quasi eksperimental design dengan rancangan posttest only control group design. Sampel penelitian ini adalah 30 responden (primipara) dalam kala I fase aktif dengan teknik purposive sampling. Instrumen penelitian ini adalah : kuesioner, Visual analogue scale, Endhorphine massage dan Panduan Endhorphine massage. Hasil penelitian menunjukkan nyeri persalinan pada kelompok kontrol sebagian besar mengalami nyeri berat sebanyak 10 orang $(66,7 \%)$. Responden yang mengalami nyeri sedang sebanyak 4 orang $(26,7 \%)$, dan nyeri sangat berat sebanyak 1 orang $(6,7 \%)$. Nyeri persalinan pada kelompok perlakuan sebagian besar mengalami nyeri ringan sebanyak 9 orang $(60,0 \%)$. Responden yang mengalami nyeri sedang sebanyak 4 orang $(26,7 \%)$ dan nyeri berat sebanyak 2 orang $(13,3 \%)$. Hasil uji independent $\mathrm{t}$-test diketahui $\mathrm{p}$ value = 0,000, hal ini menunjukan bahwa ada pengaruh endorphin massage terhadap intensitas nyeri kala I persalinan normal ibu primipara di BPS S dan B Demak bahwa ada $(\mathrm{p}<0,05)$.

Handayani, Winarni, \& Sadiyanto (2013) melakukan penelitian tentang pengaruh massage effleurage terhadap pengurangan intensitas nyeri persalinan kala I fase aktif pada primipara di RSIA Bunda Arif Purwokerto. Penelitian ini adalah untuk mengetahui pengaruh metode massage effleurage terhadap pengurangan intensitas nyeri persalinan kala I fase aktif pada primipara sebelum dan sesudah intervensi. Penelitian ini menggunakan bentuk pre eksperimen dengan desain one group pretest-postest. Penelitian dilakukan pada bulan April-Mei 2011. Pengambilan sampel dengan consecutive sampling dengan besar sampel 34 responden primipara. Instrument yang digunakan lembar observasi dengan NRS. Analisis bivariat menggunakan uji "pair t test". Pengumpulan data mengunakan instrument numerical rating scale (NRS). Hasil penelitian diperoleh intensitas nyeri sebelum dilakukan metode massage effleurage rata-ratanya adalah 7,647. Setelah dilakukan metode massage effleurage diperoleh rata-ratanya adalah 6,117. Nilai perbedaan rata-rata sebelum dan sesudah dilakukan metode massage effleurage adalah 1,53 (t-hitung: 8,260 dan t-tabel: 1,960).Dengan nilai $\mathrm{p}(0,000)<\alpha$ 
$(0,050)$. Ada perbedaan yang signifikan antara intensitas nyeri sebelum dilakukan dan setelah dilakukan metode massage effleurage.

Penelitian oleh Nurrochmi, Nurasih, \& Romadon (2014) bertujuan untuk mengetahui pengaruh kombinasi Metode Zilgrei dan Endorphin Massage pada ibu inpartu primigravida terhadap lamanya kala I fase aktif di RSUD Indramayu Periode April-Mei 2013. Desain penelitian adalah Quasi-Eksperimental dengan menggunakan Nonrandomized Concurrent Control (uji kontrol bersamaan nonrandom). Sampel penelitian adalah ibu inpartu primigravisa dengan teknik purposive sampling, dimana sampel diberi perlakuan metode Zilgrei dan endorphin massage sebagai kelompok intervensi, sedangkan yang hanya diberi perlakuan metode Zilgrei sebagai kelompok kontrol. Alat pengukuran yang digunakan dalam penelitian ini adalah partograf WHO dan Visual Analogue Scale (VAS). Pengamatan variabel dilakukan dengan melakukan observasi kemajuan persalinan khususnya pada pembukaan serviks kala I fase aktif persalinan (dimulai dari pembukaan 4-10 cm) dan mengukur intensitas nyeri responden dengan lembar pengkajian intensitas nyeri atau kuesioner. Analisis menggunakan uji beda dua mean $\mathrm{t}$ test. Hasil penelitian didapatkan bahwa rata-rata intensitas nyeri pada kala I fase laten adalah 3.35 (95\% CI: 2.92-3.79), dengan standar deviasi 1.199. Intensitas nyeri terendah yaitu 1 dan intensitas nyeri tertinggi yaitu 6. Dari hasil estimasi interval dapat disimpulan bahwa $95 \%$ diyakini bahwa rata-rata intensitas nyeri pada kala I fase laten adalah diantara 2.92 sampai dengan 3.79. Dapat diketahui bahwa ratarata intensitas nyeri pada kala I fase aktif adalah 5.87 (95\% CI: 5.35-6.39), dengan standar deviasi 1.408. Intensitas nyeri terendah yaitu 3 dan intensitas nyeri tertinggi yaitu 8. Dari hasil estimasi interval dapat disimpulan bahwa 95\% diyakini bahwa rata-rata intensitas nyeri pada kala I fase aktif adalah diantara 5.35 sampai dengan 6.39. Adanya pengaruh bermakna antara pemberian metode Zilgrei dan Endorphine massage terhadap intensitas dan lamanya nyeri kala I persalinan.

\section{Metode Hypnobirthing}

Penelitian oleh Armi \& Oktriani (2016) yang bertujuan untuk mengetahui efektivitas hypnobirthing terhadap skala nyeri persalinan ibu inpartu Kala I fase aktif di Wilayah Kerja Puskesmas Malalo Kec. Batipuh Selatan Kab. Tanah Datar. Desain penelitian yang digunakan adalah metode penelitian "Quasi Eksperimental" dengan jenis desain "One Group Pretest and Posttest Design" yang dilakukan pada bulan Juli sampai dengan September. Sampel penelitian sebanyak 6 orang responden dengan teknik pengambilan sampel Nonprobability sampling (Purposive sampling) dan pengolahan data menggunakan uji t-test dependen (paired test). Hasil penelitian didapatkan rerata nyeri sebelum dilakukan hypnobirthing adalah 8.50, dan setelah dilakukan hypnobirthing adalah nyeri 6.00. Setelah dilakukan uji test dengan menggunakan paired sampel test didapatkan nyeri persalinan ( $p$ value $=0.007$ ), yang berarti bahwa ada efektivitas hypnobirthing terhadap skala nyeri persalinan pada ibu inpartu kala 1 fase.

\section{Musik Religi dan Murottal}

Terapi murotal dapat mempercepat penyembuhan, hal ini telah dibuktikan oleh berbagai ahli seperti yang telah dilakukan Ahmad Al Khadi direktur utama Islamic Medicine Institute for Education and Research di Florida, Amerika Serikat. Dalam konferensi tahunan ke XVII Ikatan 
Dokter Amerika, dengan hasil penelitian bahwa mendengarkan ayat suci Al-Quran memiliki pengaruh yang signifikan dalam menurunkan ketegangan urat saraf reflektif dan hasil ini tercatat dan terukur secara kuantitatif dan kualitatif oleh alat berbasis komputer (Remolda, 2009 cit Rohmi Handayani, Dyah Fajar sari, Dwi Retno Trisna Asih, 2014). Penelitian yang dilakukan oleh Rohmi Handayani, Dyah Fajar sari, Dwi Retno Trisna Asih (2014) bertujuan untuk mengetahui perbedaan rerata penurunan intensitas nyeri dan kecemasan persalinan primigravida kala I fase aktif sebelum dan sesudah dilakukan terapi murottal di RSUD. Prof. Dr. Margono Soekardjo Purwokerto. Penelitian ini adalah pre-eksperimen dengan rancangan one group pretest and posttest design. Sampel penelitian ini sebanyak 42 ibu bersalin dengan teknik consecutive sampling. Analisis menggunakan uji paired $\mathrm{t}$ test. Rata-rata intensitas nyeri sebelum terapi murottal adalah 6,57, rata-rata setelah dilakukan terapi murottal adalah 4,93. Uji Paired $\mathrm{t}$ test menunjukkan bahwa ada perbedaan rerata penurunan intensitas nyeri persalinan kala I fase aktif sebelum dan sesudah dilakukan terapi murottal dengan nilai $\mathrm{p}$ value $<\alpha(0,000<0,05)$. Rata-rata kecemasan sebelum terapi murottal adalah 26,67, rata-rata setelah dilakukan terapi murottal adalah 20,52. Uji Paired t test menunjukkan bahwa ada perbedaan rerata penurunan tingkat kecemasan sebelum dan dan sesudah dilakukan terapi murottal dengan nilai $p$ value $<\alpha(0,000<0,05)$.

Musik religi menjadi focus penelitian yang membahas tentang aplikasi terapi musik religi sebagai upaya menurunkan skala nyeri persalinan di Kab. Kudus Tahun 2015 yang diteliti oleh Karyati \& Hidayah (2015). Penelitian ini menggunakan metode intervensi semu (quasi experiment), rancangan post test with control group dengan intervensi terapi musik religi. Populasi penelitian ini ibu bersalin spontan di BPM di Kabupaten Kudus sebanyak 420 orang. Jumlah sampel 66 terdiri dari 33 orang kelompok intervensi dan 33 orang kelompok control. Sampel diambil secara insidential sampling. Penelitian ini menggunakan lembar observasional untuk mengobservasi skala nyeri responden selama persalinan kala I sampai memasuki kala II. Analisa data dilakukan dengan uji ttest independent. Hasil penelitian didapatkan rata-rata usia responden adalah 26,15 , paritas anak kedua $(43,90 \%)$, ratarata skala nyeri maksimal dan persalinan pada kelompok intervensi 4,33 dan 3,33 sedangkan pada kelompok control keduanya 7,99. Simpulannya terdapat perbedaan signifikan skala nyeri antara kelompok yang mendapat terapi music religi dengan yang tidak mendapatkannya dengan nilai $\mathrm{p}=0,00$.

\section{Metode Musik Klasik dan Daerah}

Penelitian oleh Somoyani, Armini, \& Erawati (2013) bertujuan untuk mengetahui pengaruh terapi musik klasik dan musik Bali terhadap intensitas nyeri persalinan kala I fase aktif pada ibu bersalin di Puskesmas Pembantu Dauh Puri tahun 2013 dan Puskesmas I Denpasar Timur. Rancangan penelitian adalah pre-post test control group design dengan pendekatan prospektif. Besar sampel 27 ibu bersalin di Puskesmas Pembantu Dauh Puri dan Puskesmas I Denpasar Timur pada Mei sampai Agustus 2013 dengan teknik consecutive sampling. Sampel dibagi menjadi tiga kelompok. Kelompok pertama diperdengarkan musik klasik Mozart, kelompok kedua musik Bali, dan kelompok ketiga sebagai kontrol tidak mendapat perlakuan. Pengukuran nyeri dilakukan dua kali (repeated measure). pertama, dilakukan 
pada saat ibu sudah berada pada fase aktif, yaitu sebelum diberi perlakuan, dan kedua setelah mendapat perlakuan mendengarkan musik sampai akhir kala I persalinannya. Pengukuran nyeri menggunakan numerical rating scale (NRS) baku, dengan kategori nyeri skala 0 ( tidak nyeri), skala 1-3 (nyeri ringan), Skala 4-6 (nyeri sedang), Skala 79 (nyeri berat), dan kala 10 (nyeri hebat). Uji Hipotesis yang digunakan uji- $t$ dua sampel berpasangan pada musik Bali karena data berdistribusi normal, sedangkan musik klasik dan kontrol digunakan uji Wilcoxon karena data tidak berdistribusi normal. Selanjutnya dilakukan uji analysis of variance (ANOVA) dengan hasil nilai $\mathrm{p}=0,00$, dilanjutkan dengan analisis post hoc, yaitu uji Mann Whitney dengan hasil antara kelompok musik klasik dan kontrol nilai $\mathrm{p}=0,001$, kelompok musik Bali dengan kontrol nilai $\mathrm{p}=0.020$. Hasil penelitian menunjukkan ada perbedaan nyeri persalinan setelah mendengarkan musik klasik Mozart dibandingkan kelompok kontrol, sama halnya setelah mendengarkan musik Bali dibandingkan kelompok kontrol.

Penelitian lainnya tentang musik dilakukan oleh Oktavia, Gandamiharja, \& Akbar, (2013) tentang music klasik Mozart dan gamelan jawa yang bertujuan untuk mengetahui efektifitas musik klasik Mozart dan tradisional gamelan jawa dapat mengurangi nyeri persalinan, dan apakah musik klasik Mozart lebih baik daripada tradisional gamelan jawa terhadap pengurangan nyeri persalinan kala I fase aktif pada nulipara. Penelitian ini menggunakan metode eksperimen semu dengan total 30 orang nulipara yang berada dalam kala I fase aktif persalinan. Penelitian dilakukan di RSIA Arvita Bunda Kabupaten Sleman Yogyakarta selama Desember 2010-Maret 2011. Subjek penelitian berada dalam 3 kelompok: Mozart $(n=10)$, gamelan jawa $(n=10)$, dan kontrol $(n=10)$. Tiap kelompok mendapat dua kali pengukuran nyeri dengan menggunakan numerical rating scale (NRS). Penilaian pertama (I) dilakukan pada saat ibu sudah berada pada fase aktif, yaitu sebelum diberi perlakuan, dan penilaian II pada akhir kala I persalinan setelah mendapat perlakuan mendengarkan musik. Musik yang diperdengarkan adalah CD relaksasi ibu dan bayi karya Mozart dan CD relaksasi gamelan jawa melalui tape portable player karena earphone dapat menambah ketidaknyamanan ibu yang sedang nyeri. Uji analisis statistik menggunakan Wilcoxon Signed Ranks (Z) dan Uji Mann Whitney. Hasil yang didapatkan antara lain, pada kelompok Mozart terdapat nilai median 7,5 (7- 10) menjadi 6 (5-9), pada kelompok gamelan jawa median 7 (5-9) menjadi 7,5 (5-10), sementara pada kontrol median 7 (4-9) menjadi 9,5 (6-10). Terdapat perbedaan nyeri antara kelompok Mozart dan kontrol $(\mathrm{p}=0,001)$, terdapat perbedaan nyeri antara kelompok gamelan jawa dan kontrol $(\mathrm{p}=0,022)$, dan perbandingan antara musik klasik Mozart dan musik tradisional gamelan jawa $(\mathrm{p}=0,124)$.

\section{Metode Relaksasi}

Penelitian tentang efektifitas teknik relaxaxi terhadap pengurangan rasa nyeri persalinan Kala I di BPS Ny. Yohana, Amd.Keb Desa Sumbertanggul Mojosari Mojokerto oleh Hety (2016) bertujuan untuk meneliti tentang efektivitas teknik relaksasi terhadap pengurangan rasa nyeri persalinan kala I. Penelitian ini adalah ekperimental dengan jenis desain yaitu static group comparison/ posttest only control group design, yaitu dengan menambah kelompok control, dengan cara setelah perlakuan di lakukan pengamatan 
pada kelompok perlakuan dan pada kelompok control di lakukan pengamatan saja. Penelitian ini menggunakan pendekatan cross sectional. Sampel penelitian penelitian ini adalah keseluruhan ibu inpartu kala I yang diperoleh dari bulan Oktober-Nopember 2009 sebanyak 15 populasi dengan menggunakan teknik non probability sampling (sampling aksidental). Hasil penelitian didapatkan nyeri pada responden yang tidak diberikan teknik relaksasi

(kelompok kontrol), sebagian besar mengalami tingkatan nyeri berat yaitu 4 responden atau sekitar $66.67 \%$ dari jumlah keseluruhan responden yang tidak diberikan teknik relaksasi (kelompok kontrol). Nyeri pada responden yang di berikan teknik relaksasi (kelompok perlakuan), hampir setengah mengalami tingkatan nyeri sedang yaitu 3 responden atau sekitar $42.86 \%$ dari jumlah keseluruhan responden yang diberikan teknik relaksasi (kelompok perlakuan). Analsis independent sampel t-test didapatkan $\mathrm{t}$ hitung lebih besar dari pada $\mathrm{t}$ tabel (7.14>2.50), sehingga disimpulkan terdapat perbedaan secara signifikan antara skala nyeri persalinan pada ibu inpartu kala I yang tidak diberikan teknik relaksasi dengan skala nyeri persalinan pada ibu inpartu kala I yang diberikan teknik relaksasi.

Penelitian relaksasi dengan nafas dalam dilakukan oleh Kusyati, Astuti, \& Pratiwi, (2012) bertujuan untuk mengetahui efektivitas teknik relaksasi nafas dalam terhadap tingkat nyeri persalinan kala I di Wilayah Kerja Puskesmas Tlogosari Wetan Semarang. Penelitian ini adalah Quasi Eksperiment dengan pendekatan Pre Post test non with control design. Sampel adalah ibu bersalin di wilayah kerja Puskesmas Tlogosari Wetan Semarang sebanyak 30 ibu dengan teknik purposive sampling. Sampel diberikan teknik relaksasi denga nafas dalam. Hasil penelitian didapatkan Nyeri sebelum teknik relaksasi rata- rata 6,80 dengan nyeri paling rendah 4 tertinggi 9. Nyeri sesudah teknik relaksasi rata- rata 5,10 dengan nyeri paling rendah 2 tertinggi 8. Sebagian besar nyeri sebelum teknik relaksasi rata-rata 6,80. Nyeri sesudah teknik relaksasi rata-rata 5,10. Teknik relaksasi nafas dalam efektif dalam menurunkan tingkat nyeri persalinan kala I di Wilayah Kerja Puskesmas Tlogosari Wetan Semarang $\mathrm{p}$ value $=0,00(\mathrm{p}<0,05)$.

\section{Metode Kompres}

Penelitian Manurung et al. (2013) bertujuan untuk mengidentifikasi pengaruh terapi kompres hangat terhadap penurunan intensitas nyeri pada persalinan kala I fase aktif. Desain penelitian adalah quasi experiment, pretest-postest dengan kelompok kontrol dan intervensi. Sampel penelitian adalah ibu primigravida yang melahirkan secara spontan di Puskesmas Kecamatan Pasar Minggu dan Cilandak dengan jumlah masingmasing untuk kedua kelompok 18 orang ibu primigravida yang akan melahirkan spontan di Puskesmas wilayah Jakarta Selatan yaitu Puskesmas Kecamatan dan Kelurahan Pasar Minggu dan Puskesmas Cilandak . Kelompok intervensi diberi terapi kompres hangat selama 20 menitperiode kala I fase aktif. Pengumpulan data dilakukan dari tanggal 5 Mei - 4 Juni 2011. Pengujian hipotesis menggunakan uji $\mathrm{T}$ test yakni paired samples t test dan $\mathrm{T}$ test independent. Hasil uji regresi linear ganda membuktikan hubungan ketiga variabel terapi kompres dan skala nyeri persalinan kala satu fase aktif sebelum periode intervensi dengan skala nyeri persalinan sesudah periode intervensi menunjukkan rentang hubungan 
yang sangat erat $(R=0,901)$. Skala nyeri sesudah periode intervensi menurun sebesar 2,07 point setiap responden diterapi dengan kompres hangat, meningkat sebesar 0,71 setiap peningkatan skala nyeri persalinan jika tidak di kontrol.

\section{Minuman Jahe Hangat}

Metode lain yang dilakukan penelitian dalam mengatasi rasa nyeri persalinan adalah dengan minuman jahe hangat. Rahmawati (2016) melakukan penelitian tentang pengaruh minuman jahe hangat dengan intensitas nyeri persalinan kala I. Penelitian ini bertujuan untuk mengetahui adanya pengaruh pemberian minum jahe hangat dengan intensitas nyeri Persalinan Kala I. Metode yang digunakan adalah quasi eksperimental dengan pendekatan one time approach. Sampel penelitian sejumlah 30 orang (kuota sampling) yang dibagi menjadi 3 kelompok yaitu 10 orang diberikan 50 gram jahe, 10 orang diberikan 25 gram jahe, dan 10 orang diberikan air putih. Penelitian diambil dari tanggal Januari - Maret 2016. Analisis data menggunakan uji one way anova. Hasil penelitian menunjukkan adanya penurunan rata-rata intensitas nyeri sebelum diberi perlakuan 7.00, dan setelah diberi perlakuan 5.00 sehingga ada pengaruh pemberian jahe dengan penurunan intensitas nyeri ( $p$ value $0,023<0,05$ ).

\section{Akupressur}

Penggunaan tehnik akupresur titik titik pada tangan sebaiknya semakin di budayakan di kalangan praktek kebidanan terutama dalam pengatasan nyeri persalinan kala I. Penelitian yang dilakukan oleh Suroso \& Mulati (2014) bertujuan untuk mengetahui Penerapan Teknik Akupresur Titik pada Tangan Terhadap Intensitas Nyeri Persalinan Kala I. Jenis penelitan ini adalah Quasi Eksperiment dengan desain Untreated Control Group Design with
Pretest and Posttest. Ibu bersalin pada kala I yang mengalami nyeri persalinan menjadi sampel penelitian, dengan tehnik pengambilan sampel secara accidental sampling. Penelitian dii ambil pada bulan Juni- Juli 2013. Sampel dibagi dalam 2 kelompok: 15 sampel untuk kelompok intervensi dan 15 sampel untuk kelompok kontrol. Analisa data yang digunakan dalam adalah T-Test jika data berdistribusi normal atau Wilxocon dan U Mann Whitney. Hasil uji wilcoxon pada pretest dan posttest kelompok intervensi menunjukkan $\mathrm{p}$ value 0.001 , dimana $\mathrm{p}<$ 0.05 yang berarti ada pengaruh yang signifikan dari tindakan akupresur titik pada tangan terhadap intensitas nyeri persalinan kala I. Hal ini berarti bahwa tindakan akupresur titik pada tangan punya pengaruh yang signifikan dalam menurunkan intensitas nyeri persalinan kala I. Hasil uji wilcoxon pada pretest dan posttest kelompok kontrol menunjukkan $\mathrm{p}$ value $=0.490$, dimana $p>0.05$ yang berarti tidak ada penurunan intensitas nyeri persalinan kala I dari pretest ke posttest karena pada kelompok kontrol tidak diberikan tindakan akupresur titik pada tangan. Kesimpulannya, hasil uji U MannWhitney menunjukkan $\mathrm{p}$ value $=0.139$, dimana $\mathrm{p}>0.05$ yang berarti tidak ada perbedaan yang signifikan antara kelompok intervensi dan kelompok kontrol pada tindakan akupresur titik pada tangan terhadap intensitas nyeri persalinan kala I.

\section{Tens}

Salah satu intervensi sensori yang mengatur transmisi stimuli nociceptive adalah Transcutaneous Electrical Nerve Stimulation (TENS). TENS adalah teknik analgesik non invansif yang sederhana. TENS secara selektif akan mengaktifkan serat raba berdiameter besar (Ab) tanpa mengaktifkan serat nociceptive 
berdiameter lebih kecil (A $\delta$ dan C), sehingga menghasilkan subtansi analgesik segmental yang dikeluarkan otak dengan cepat dan terlokalisir pada dermatom yang bekerja pada system saraf pusat dan saraf perifer untuk mengurangi nyeri. Penelitian oleh Yulifah, Moersintowarti, \& Purnomo (2009) tentang Penggunaan Stimuli Transcutaneous Electrical Nerve Stimulation (Tens) Dapat Menurunkan Intensitas Nyeri dan Tingkat Kecemasan pada Persalinan Kala I. Penelitian ini bertujuan untuk untuk mempelajari efek penggunaan TENS dalam menurunkan intensitas nyeri serta kecemasan pada persalinan kala I. Desain penelitian ini adalah experimental dengan PretestPosttest Control Group Design Sampel berjumlah 20 orang terdiri dari 2 kelompok, yaitu kelompok perlakuan dan kelompok kontrol. Masing-masing kelompok terdiri dari 10 ibu yang sedang melahirkan di kamar bersalin Rumah Sakit Haji Kota Batu, yang diambil dengan metode consecutive sampling. Kelompok perlakuan akan diberi stimuli sensori Transcutaneous Electrical Nerve Stimulation (TENS), yaitu suatu teknik analgesik non invansif sederhana dalam bentuk elektro stimulasi, dengan dua pasang elektroda yang ditempelkan pada permukaan kulit (punggung) ibu bersalin kala I, sedangkan kelompok kontrol adalah ibu yang menerima asuhan standar. Efek yang diamati adalah intesitas nyeri dan tingkat kecemasan saat persalinan kala I. Intensitas nyeri diukur dengan Bourbonnais scale dengan skala 0-10 dan dikelompokkan menjadi 5 kategori, yaitu 1) tidak nyeri (skala 0 ), nyeri ringan (skala $1-$ 3), nyeri sedang (skala 4-6), nyeri berat (skala 7-9), nyeri hebat (skala 10). Cara pemakaian TENS yaitu pasien disiapkan dalam posisi senyaman mungkin, elektroda dipasang dengan jarak 1-2 cm di kanan kiri antara T10 sampai L1. Alat ini diberikan pada saat terjadi his dengan intensitas 1-10 mulai dari yang terkecil dan bertahap, selama 15 menit. Tingkat kecemasan diukur dengan menggunakan HRS-A (Hamilton Rating Scale for Anxiety), yaitu instrumen yang berupa lembar observasi tingkat kecemasan yang terdiri dari 14 kelompok gejala yang diberi penilaian antara $0-4$ sebagai berikut: nilai $0=$ bila tidak ada satupun gejala yang muncul, $1=$ jika ada 1 gejala yang muncul, $2=$ jika ada 2 gejala yang muncul, $3=$ jika ada 3 gejala yang muncul, 4 = jika semua gejala muncul. Tingkat kecemasan dikategorikan: 1) tak ada kecemasan (skor < 14), cemas ringan (skor 14-20), cemas sedang (skor 21-27), cemas berat (skor 28-41), dan panik (skor 42-56) (Corcoran, 1994). Pengujian hipotesis dilakukan dengan menggunakan Wilcoxon Signed Rank, dengan signifikansi $\mathrm{a}=0,05$. Sedangkan untuk melihat ada perbedaan sebelum dan sesudah pemberian stimulasi TENS digunakan statistik non parametrik dengan uji Mann-Whitney Test dengan taraf signifikansi a $=0,05$.

Hasil analisis uji statistik Wilcoxon Signed Rank intensitas nyeri dan tingkat kecemasan sebelum diberikan perlakuan baik pada kelompok perlaukan maupun kelompok kontrol menunjukkan tidak ada perbedaan yang signifikan dengan diperoleh $\mathrm{p}=0,176(\mathrm{a}=0,05)$ untuk intensitas nyeri dan $\mathrm{p}=0,466(\mathrm{a}=0,05)$ untuk tingkat kecemasan. Perbandingan intensitas nyeri dan tingkat kecemasan antara sebelum dan sesudah perlakuan pada kedua kelompok. Ada perbedaan intensitas nyeri dan tingkat kecemasan yang bermakna sebelum dan sesudah diberikan stimulasi TENS, dengan $\mathrm{p}=0,005$ untuk intensitas nyeri dan $p=0,000$ untuk tingkat 
kecemasan, sedangkan pada kelompok kontrol tidak ada perbedaan yang bermakna intensitas nyeri $(\mathrm{p}=0,826)$ dan tingkat kecemasan $(p=0,066)$ antara sebelum dan sesudah diberikan asuhan standar. Intensitas nyeri dan tingkat kecemasan setelah diberikan perlakuan baik pada kelompok intervensi maupun kelompok kontrol menunjukkan ada perbedaan yang signifikan dengan diperoleh $\mathrm{p}=0,000(\mathrm{a}=$ 0,05). Adanya perbedaan perubahan intensitas nyeri dan tingkat kecemasan yang signifikan antara kelompok kontrol dengan kelompok intervensi, dengan diperoleh $\mathrm{p}=$ 0,000 .

\section{Acount}

Nasriyah \& Nisak (2015) melakukan penelitian tentang acount. Tujuan penelitian ini adalah untuk meneliti tentang pengaruh metode akupresur dan counterpressure terhadap penurunan intensitas nyeri persalinan kala I fase aktif untuk mengetahui metode apa yang lebih berpengaruh bila diterapkan pada ibu bersalin kala I fase aktif. Desain penelitian adalah intervensi semu (quasi experiment) dengan rancangan pre-pot test one group dengan menggunakan intervensi metode Acount, pendekatan pre-pot test one group design digunkan untuk melihat efektifitas sebelum dan setelah diberikan perlakukan metode Acount. Sampel penelitian adalah ibu primipara yang bersalin normal di Klinik Lydya Sifra dan BPM Leny Mulyani Kabupaten Kudus dengan jumlah sampel 36 responden. Analisis kuantitatif dengan menggunakan uji Wilcoxon untuk melihat perbedaan dan efektifitas sebelum dan setelah diberikan metode Acount. Hasil uji statistik dengan menggunakan uji Wilcoxon menunjukkan nilai significancy $0,000(\mathrm{p}<0,05)$, dengan demikian terdapat perbedaan skala nyeri antara sebelum diberikan metode ACOUNT dengan setelah diberikan metode ACOUNT.

\section{Aromatherapi}

Aromaterapi merupakan salah satu metode nonfarmakologis yang digunakan untuk meningkatkan kesehatan fisik dan psikologis. Salah satunya adalah aromaterapi jasmine (bunga melati) yang telah digunakan secara tradisional sebagai bantuan dalam kelahiran. Melati dapat membantu memperkuat kontraksi, yang juga memiliki kandungan pereda nyeri dan antispasmodik. Secara emosional, melati memiliki kualitas memberikan energi dan antidepresan. Aromaterapi jasmine mempunyai efek positif karena diketahui bahwa aroma yang segar, harum merangsang sensori, reseptor dan pada akhirnya mempengaruhi organ yang lainnya sehingga dapat menimbulkan efek kuat terhadap emosi. Peelitian yang dilakukan oleh Lilin dan Citra (2015) tentang efektifitas aromaterapi jasmine terhadap pengurangan rasa nyeri persalinan. Desain penelitian adalah Trueexperiment dengan pendekatan pretest dan posttest with control group. Sampel penelitian sejumlah 32 responden yaitu 16 responden pada kelompok yang diberi aroma jasmine selama kala I fase aktif dan 16 responden pada kelompok control tidak diberikan aroma jasmine. Pengambilan data dilakukan mulai bulan Januari sampai dengan April 2015. Penelitian dilakukan di dua tempat yaitu BPM Ny. "Y" untuk pengambilan data kelompok perlakukan dan BPM Ny. "T" untuk kelompok kontrol. Intensitas nyeri sebelum diberi aroma jasmine pada kelompok perlakuan yaitu 13 responden $(41 \%)$ mengalami nyeri sedang dan 3 responden $(25 \%)$ mengalami nyeri berat. Pada kelompok control didapatkan hasil intensitas nyeri 8 responden (25\%) 
dengan nyeri sedang dan 8 responden (25\%) dengan nyeri berat. Setelah pemberian aroma jasmine, intensitas nyeri pada kelompok perlakuan yaitu 16 responden $(50 \%)$ mengalami nyeri. Pada kelompok control didapatkan hasil intensitas nyeri 12 responden (38\%) dengan nyeri sedang dan 4 responden (4\%) dengan nyeri berat. Hasil uji Wilcoxon Sum Rank Test didapatkan hasil $\mathrm{p}=0,008$ yang berarti terdapat pengaruh pemberian aroma jasmine terhadap intensitas nyeri ibu bersalin kala I.

\section{SIMPULAN}

Dalam upaya mengurangi rasa nyeri persalinan terdapat berbagai metode yang dapat digunakan dalam memberikan asuhan kebidanan dalam proses persalinan. Berdasarkan systematic review ini dapat disimpulkan bahwa banyak metode pengurangan rasa nyeri yang dapat digunakan dalam mengurangi nyeri proses persalinan adalah metode counter pressure dan abdominal lifting, hypnobirthing, music religi dan murottal, music klasik dan music daerah, relaksasi, kompres, minuman jahe hangat, akupressur, TENS, account dan aromatherapy. Berdasarkan hasil systematic review ini, bidan sebagai tenaga professional yang langsung memberikan pelayanan kebidanan khususnya dalam proses persalinan dapat mempertimbangkan metode pengurangan rasa nyeri berbagai metode yang dapat digunakan dalam memberikan asuhan kebidanan persalinan untuk mengurangi rasa nyeri persalinan sehingga tidak menimbulkan kesematan yang dapat mempengaruhi proses persalinan sehingga menghindari angka kesakitan dan kematian ibu dan bayi.

\section{UCAPAN TERIMA KASIH}

Ucapan terima kasih disampaikan Kepada Yayasan Tengku Maharatu Pekanbaru Riau dan STIKes Tengku Maharatu Pekanbaru Riau.

\section{DAFTAR PUSTAKA}

Afifah, D., Mulyono, B., \& Pujiati, N. 2012. Perbedaan Tingkat Nyeri Persalinan Kala I Pada Ibu Bersalin Normal Primigravida Dan Multigravida Di Rb Nur Hikmah Desa Kuwaron Gubug Kabupaten Grobogan Tahun 2011. Jurnal.unimus.ac.id. 1(1) : 1-10.

A, Afritayeni. 2017. Hubungan umur, paritas dan pendamping persalinan dengan intensitas nyeri persalinan kala i. Journal Endurance. 2(June) : 178185.

Angraeni, P. D., Er, H. S., Wijayanti, K., Studi, P., Keperawatan, I., \& Muhammadiyah, U. 2013. Efektifitas Teknik Abdominal Lifting Dan Counter Pressure Effectiveness Technic of Abdominal Lifting and Counter Pressure in the Fight Labor Pains Active Phase I At General Goverment Tidar Hospital Magelang. Jurnal Tidak Dipublikasi Universitas Muhammadiyah Magelang.

Armi, Y., \& Oktriani, T. 2016. Efektivitas Hypnobirthing Terhadap Skala Nyeri Persalinan Ibu Inpartu Kala I Fase Aktif Di Wilayah Kerja Puskesmas Malalo Kec. Batipuh Selatan Kab. Tanah Datar. Jurnal Kesehatan STIKes Prima Nusantara Bukittinggi. 5(2) : 36-46.

Azizah, I. N., Widyawati, M. N., \& Anggraini, N. N. 2011. Pengaruh Endorphin Massage Terhadap Intensitas Nyeri Kala I Persalinan Normal Ibu Primipara di BPS S dan B Demak Tahun 2011. Jurnal.unimus.ac.id. 53(9) : 90-96. https://doi.org/10.1017/CBO9781107 415324.004

Handayani, R., Winarni, \& Sadiyanto. 
2013. Pengaruh Massage Effleurage Terhadap Pengurangan Intensitas Nyeri Persalinan Kala I Fase Aktif Pada Primipara di RSIA Bunda Arif Purwokerto Tahun 2011. Jurnal Kebidanan. V(1) : 66-73.

Hety, D. S. 2016. Efektifitas Teknik Relaxaxi Terhadap Pengurangan Rasa Nyeri Persalinan Kala I di BPS Ny. Yohana, Amd.Keb Desa Sumbertanggul Mojosari Mojokerto. Medica Majapahit. 8(1) : 14-21.

Karyati, S., \& Hidayah, N. 2015. Aplikasi Terapi Musik Religi Sebagai Upaya Menurunkan Skala Nyeri Persalinan di Kab. Kudus Tahun 2015. The 2nd University Research Coloquium 2015. Kusyati, E., Astuti, L. P., \& Pratiwi, D. D. 2012. Efektifitas Teknik Relaksasi Nafas Dalam Terhadap Tingkat Nyeri Persalinan Kala I di Wilayah Kerja PUSKESMAS Tlogosari Wetan Semarang Tahun 2012. Jurnal Kebidanan. IV(2) : 93-100.

Manurung, S., Nuraeni, A., Lestari, T. R., Soleha, I., Suryati, Nurhaeni, H., ... Rahmawaty, E. 2013. Pengaruh Tehnik Pemberian Kompres Hangat Terhadap Perubahan Skala Nyeri Persalinan Pada Klien Primigravida dan Puskesmas Cilandak Jakarta Selatan. Jurnal Health Quality. 4(1) : 1-8.

Nasriyah, N., \& Nisak, A. 2015. Kombinasi Metode Acount Untuk Penurunan Nyeri Persalinan.T he 2nd University Research Coloqium 2015: 114-118.

Nurrochmi, E., Nurasih, \& Romadon, R. A. 2014. Pengaruh Kombinasi Metode Zilgrei dan Endorphin Massage pada Ibu Inpartu Primigravida Terhadap Lamanya Kala I Fase Aktif DI RSUD Indramayu Periode April-Mei 2013. Jurnal CARE. 2(2) : 23-31.

Oktavia, N. S., Gandamiharja, S., \& Akbar, I. B. 2013. Perbandingan Efek Musik Klasik Mozart dan Musik Tradisional Gamelan Jawa terhadap Pengurangan Nyeri Persalinan Kala I Fase Aktif pada Nulipara. MKB. 45(4) : 218-225
Rahmawati, I. 2016. Pengaruh Pemberian Minum Jahe Hangat Dengan Intensitas Nyeri Pada Persalinan Kala I Di Rsia Kumalasiwi Kabupaten Jepara. Jurnal Kebidanan. 5(2) : 69-75

Rohmi Handayani, Dyah Fajar sari, Dwi Retno Trisna Asih, D. N. R. 2014. Pengaruh terapi Murotal Al-Quran untuk penurunan nyeri persalinan dan kecemasan pad ibu bersalin kala I fase aktif. Jurnal Ilmiah Kebidanan. 5(2) : $1-15$.

Sari, F. S., \& Novriani, W. 2017. Dukungan Keluarga dengan Kecemasan Menjelang Persalinan Trimester III. Jurnal Ipteks Terapan 11(1) : 55-64.

Somoyani, N., Armini, N., \& Erawati, N. S. 2013. Terapi Musik Klasik dan Musik Bali Menurunkan Intesitas Nyeri Persalinan Kala II Fase Aktif. Jurnal Skala Husada. 11(1) :18-23.

Suroso, \& Mulati, T. S. 2014. Penerapan Teknik Akupresur Titik pada Tangan Terhadap Intensitas Nyeri Persalinan Kala I. Jurnal Terpadu Ilmu Kesehatan. 3(1) : 93-98.

Yulifah, R., Moersintowarti, B. N., \& Purnomo, W. 2009. Penggunaan Stimuli Transcutaneous Electrical Nerve Stimulation ( Tens ) Dapat Menurunkan Intensitas Nyeri dan Tingkat Kecemasan pada Persalinan Kala I. The Indonesian Journal of Public Health. 5 : 119-123. 